\title{
Correction to: Megan Swift: Picturing the Page: Illustrated Children's Literature and Reading Under Lenin and Stalin
}

\author{
Jennifer Ladwig ${ }^{1}$
}

(c) Springer Science+Business Media, LLC, part of Springer Nature 2021

\section{Correction to: Publishing Research Quarterly (2021) 37:130-132 https://doi.org/10.1007/s12109-021-09788-8}

The article Megan Swift: Picturing the Page: Illustrated Children's Literature and Reading Under Lenin and Stalin, written by Jennifer Ladwig, was originally published online on 25 January 2021 with Open Access under a Creative Commons Attribution (CC BY) licence 4.0. After publication in volume 37, issue 1, pages 130-132, the author decided to cancel the Open Access. Therefore, the copyright of the article has been changed on 9 June 2021 to $(1)$ Springer Science + Business Media, LLC, part of Springer Nature 2021 with all rights reserved.

Publisher's Note Springer Nature remains neutral with regard to jurisdictional claims in published maps and institutional affiliations.

The original article can be found online at https://doi.org/10.1007/s12109-021-09788-8.

Jennifer Ladwig

jennifer.ladwig@ooliganpress.pdx.edu

1 Washougal, USA 